\title{
Geographic Variability of Sugars and Organic Acids in Selected Wild Fruit Species
}

\author{
Asima Akagić ${ }^{1, * \mathbb{D}}$, Amila Vranac Oras ${ }^{1}$, Sanja Oručević Žuljević ${ }^{1}$, Nermina Spaho ${ }^{1}$, \\ Pakeza Drkenda ${ }^{1}$, Amna Bijedić ${ }^{1}$, Senad Memić ${ }^{1}$ and Metka Hudina ${ }^{2}$ \\ 1 Faculty of Agriculture and Food Sciences, University of Sarajevo, Zmaja od Bosne 8, \\ 71000 Sarajevo, Bosnia and Herzegovina; vranac.amila@gmail.com (A.V.O.); \\ s.orucevic-zuljevic@ppf.unsa.ba (S.O.Ž.); n.spaho@ppf.unsa.ba (N.S.); p.drkenda@ppf.unsa.ba (P.D.); \\ bijedic.amna@gmail.com (A.B.); sbhsarajevo@gmail.com (S.M.) \\ 2 Department of Agronomy, University of Ljubljana, Biotechnical Faculty, Jamnikarjeva 101, \\ 1000 Ljubljana, Slovenia; metka.hudina@bf.uni-lj.si \\ * Correspondence: a.akagic@ppf.unsa.ba
}

Received: 25 February 2020; Accepted: 1 April 2020; Published: 8 April 2020

check for updates

\begin{abstract}
The chemical variability of bilberry (Vaccinium myrtillus L.), wild strawberry (Fragaria vesca L.), cornelian cherry (Cornus mas L.) and rosehip (Rosa canina L.) based on the content of individual and total sugars and organic acids in fruit was investigated. The fruits were picked in fully ripened condition within the period from 2014 to 2015 from different locations. The fresh fruits were analyzed with the high performance liquid chromatography (HPLC) technique for the purpose of identifying and quantifying the content of glucose, fructose and sucrose, as well as malic, citric, fumaric and shikimic acids. However, the content of individual sugars and organic acids differed by locations as well as by growing year within the same wild fruit species. The differences between wild fruit species as well as among different locations are presented by principal component analysis (PCA). Based on results obtained, rosehip fruits with higher sugars and organic acids ratio (S/A) are suitable for production of "pekmez" and drying, while genotypes of cornelian cherry, wild strawberry and bilberry with lower S/A are recommended for production of juices and gelatin products. The research results show that specific environmental conditions may influence significantly the content of analyzed parameters, as is the case with cornelian cherry and rosehip. Considering that the food industry is searching for new products, the wild fruit species analyzed represent a promising source of ingredients for the development of beverages and foods with functional properties as well as for supplements and nutraceuticals.
\end{abstract}

Keywords: wild fruit; sugars and organic acids; HPLC analyses; processing; pedoclimatic conditions

\section{Introduction}

Traditional wild fruit is an important foodstuff in the local population's nutrition, and it has been used in folk medicine since ancient times. Increased interest in wild fruit results primarily from the need for biodiversity preservation and use as a potential source of new nutraceuticals aimed at prevention of a series of diseases [1,2]. In addition, it improves the living conditions of the population in local rural areas, who exclusively engage in collecting and selling wild fruit and medicinal herbs, which are often their only sources of income [3]. The nutritionally valuable wild fruit, exhibiting high tolerance to different ecological and pedological conditions, and diseases and pests [4,5], is highly appreciated by consumers. This fruit, in comparison with cultivated ones, contains a higher concentration of bioactive components [6-10], which have a positive impact on health [11-15]. However, its chemical composition varies, and it is under the influence of a series of factors before and after harvesting [16-23]. Research of 
climate differences conditioned by geographical environment is very important from the perspective of comprehending the differences in fruit quality (content of sugars, organic acids, bioactive components etc.) and for optimizing the ripening stage [24-28], which are essential parameters of fruit quality.

Sugars and organic acids are the most common soluble constituents of fruit. They have an important influence on taste, shelf life and nutritive properties, and they are reliable indicators of acceptability by consumers [29-32]. Changes in sugar and organic acid composition and concentration are reflected also on changes of fresh fruit quality and their products [29]. From a technological perspective, they are very important for formation of gel consistency in gelatin products [33] and in production of juices and nectars, since they define sweetness index [34]. The representation of individual sugars and organic acids serves also as an indicator of authenticity of fruit products [35-37]. In addition, sugars participate in polyphenol biosynthesis [38]; thus, higher sugar content in fruit implies higher polyphenol concentration [39,40], which is exceptionally important from the perspective of a nutrient-enriched diet.

As far as biodiversity of forest flora is concerned, Bosnia and Herzegovina $(\mathrm{B} \& \mathrm{H})$ is among the richest countries in Europe [41]. Most of the forest plant species identified in $\mathrm{B} \& \mathrm{H}$, according to World Health Organization $(\mathrm{WHO})$ recommendations, may satisfy daily needs for basic nutrients, especially vitamins A and C, and some mineral substances [3]. According to research of Marjanovic-Balaban et al. [42], wild berries originating from $\mathrm{B} \& \mathrm{H}$, due to appropriate climate conditions and altitude, are very rich in chemical components, which have a protective impact on consumer's health. Based on the fact that wild fruit species such as rosehip, cornelian cherry, wild strawberry and bilberry occur widely and are economically the most important, having a great market value in $\mathrm{B} \& \mathrm{H}$, they were selected for investigation in this paper. Furthermore, the fruits of wild strawberry and bilberry are processed by the local population into valuable end products such as juice, jam and marmalade, and reach high prices on the market, which also improves their living conditions. According to recent literature, there are no data on sugar and organic acid profiles of wild strawberry and bilberry fruits collected at altitudes above $1000 \mathrm{~m}$. Much of the literature focuses on the analysis of basic parameters of chemical composition of this valuable fruit in B\&H [42-46]. However, there are no studies where the content of individual sugars and organic acids is determined in relation to wild fruit, except for cornelian cherry [19,47], and these are important parameters of quality of fruit and fruit products. Therefore, this paper aims at (i) determining individual sugars and organic acids content in wild fruit species, (ii) establishing the influence of location and growing year on fruit quality parameters, (iii) recommending to producers the processing of wild fruit species according to the sugars and organic acids ratio (S/A) and (iv) analyzing the relationship of individual locations' pedoclimatic data and chemical parameters of wild fruit species.

\section{Materials and Methods}

\subsection{Fruit Material}

Meteorological data were obtained from different locations in Bosnia and Herzegovina where fruit from naturally occurring flora (rosehip (dog rose), cornelian cherry, wild strawberry and bilberry) without anthropogenic influence was picked during 2014 and 2015 (Table 1). These wild fruit species are widely distributed and economically the most important, having great market value in $\mathrm{B} \& \mathrm{H}$.

Table 1. Monthly meteorological data for the growing regions in Bosnia and Herzegovina that were analyzed.

\begin{tabular}{|c|c|c|c|c|c|c|c|c|c|c|c|c|c|c|c|}
\hline \multirow{3}{*}{\multicolumn{2}{|c|}{ Month/Growing Season }} & \multicolumn{14}{|c|}{ Location/Meteorological Date } \\
\hline & & \multicolumn{2}{|c|}{ Bugojno* } & \multicolumn{2}{|c|}{ Drvar * } & \multicolumn{2}{|c|}{ Foča ** } & \multicolumn{2}{|c|}{ Konjic* } & \multicolumn{2}{|c|}{ Romanija ** } & \multicolumn{2}{|c|}{ Bjelašnica * } & \multicolumn{2}{|c|}{ Fojnica * } \\
\hline & & $\mathrm{Tm}$ & Ppt & $\mathrm{Tm}$ & Ppt & $\mathrm{Tm}$ & Ppt & $\mathrm{Tm}$ & Ppt & $\mathrm{Tm}$ & Ppt & Tm & Ppt & $\mathrm{Tm}$ & Ppt \\
\hline \multirow{2}{*}{ January } & 2014 & 4.6 & 70.4 & 4.7 & 125.7 & 4.1 & 52.1 & 3.1 & 162.7 & 2.0 & 37.5 & -2.7 & 91.0 & 5.0 & 55.3 \\
\hline & 2015 & 0.1 & 90.1 & 1.6 & 121.9 & 0.6 & 161.5 & -1.0 & 222.9 & -2.5 & 89.9 & -5.7 & 173.4 & 0.9 & 112.6 \\
\hline \multirow{2}{*}{ February } & 2014 & 7.2 & 41.1 & 5.8 & 195.1 & 6.9 & 20.5 & 4.7 & 74.9 & 4.4 & 10.8 & -2.7 & 78.7 & 7.8 & 19.9 \\
\hline & 2015 & 1.3 & 43.9 & 1.2 & 59.9 & 2.2 & 52.6 & -0.7 & 109.9 & -1.3 & 56.1 & -6.9 & 131.0 & 1.7 & 56.6 \\
\hline
\end{tabular}


Table 1. Cont.

\begin{tabular}{|c|c|c|c|c|c|c|c|c|c|c|c|c|c|c|c|}
\hline \multirow{3}{*}{\multicolumn{2}{|c|}{ Month/Growing Season }} & \multicolumn{14}{|c|}{ Location/Meteorological Date } \\
\hline & & \multicolumn{2}{|c|}{ Bugojno* } & \multicolumn{2}{|c|}{ Drvar* } & \multicolumn{2}{|c|}{ Foča ** } & \multicolumn{2}{|c|}{ Konjic* } & \multicolumn{2}{|c|}{ Romanija ** } & \multicolumn{2}{|c|}{ Bjelašnica * } & \multicolumn{2}{|c|}{ Fojnica * } \\
\hline & & $\mathrm{Tm}$ & Ppt & $\mathrm{Tm}$ & Ppt & $\mathrm{Tm}$ & Ppt & $\mathrm{Tm}$ & Ppt & $\mathrm{Tm}$ & Ppt & $\operatorname{Tm}$ & Ppt & $\mathrm{Tm}$ & Ppt \\
\hline \multirow{2}{*}{ March } & 2014 & 7.8 & 34.7 & 7.3 & 59.0 & 8.2 & 74.6 & 5.4 & 109.5 & 4.8 & 63.6 & -2.5 & 109.0 & 8.1 & 67.3 \\
\hline & 2015 & 5.3 & 55.1 & 5.3 & 46.4 & 5.4 & 91.2 & 2.3 & 126.7 & 2.1 & 74.7 & -5.5 & 143.8 & 5.3 & 80.4 \\
\hline \multirow{2}{*}{ April } & 2014 & 10.5 & 153.6 & 10.8 & 178.9 & 11.4 & 156.3 & 7.6 & 184.9 & 7.6 & 153.9 & -0.1 & 210.7 & 10.2 & 148.5 \\
\hline & 2015 & 9.1 & 47.7 & 9.2 & 26.6 & 9.6 & 54.6 & 6.2 & 83.8 & 6.2 & 53.2 & -2.8 & 73.3 & 9.2 & 43.6 \\
\hline \multirow{2}{*}{ May } & 2014 & 13.4 & 125.7 & 13.1 & 195.9 & 14.1 & 118.4 & 9.9 & 188.9 & 10.7 & 260.7 & 3.1 & 185.8 & 13.5 & 186.2 \\
\hline & 2015 & 15.6 & 60.0 & 15.3 & 111.1 & 16.5 & 51.9 & 12.9 & 41.2 & 13.4 & 75.4 & 5.6 & 38.2 & 16.1 & 52.9 \\
\hline \multirow{2}{*}{ June } & 2014 & 17.6 & 96.0 & 17.9 & 116.3 & 18.4 & 123.9 & 14.5 & 168.8 & 15.2 & 170.0 & 7.6 & 170.1 & 17.5 & 125.1 \\
\hline & 2015 & 18.0 & 72.6 & 18.0 & 55.9 & 18.2 & 121.3 & 14.9 & 94.9 & 15.3 & 113.3 & 7.7 & 118.6 & 17.8 & 91.0 \\
\hline \multirow{2}{*}{ July } & 2014 & 18.7 & 161.5 & 19.0 & 89.5 & 19.5 & 134.1 & 16.1 & 112.3 & 17.0 & 76.2 & 9.5 & 198.5 & 19.5 & 73.3 \\
\hline & 2015 & 22.7 & 67.6 & 22.7 & 25.2 & 22.7 & 23.2 & 19.7 & 21.2 & 19.8 & 25.2 & 13.9 & 25.7 & 23.2 & 9.4 \\
\hline \multirow{2}{*}{ August } & 2014 & 19.2 & 67.5 & 19.4 & 81,2 & 19.8 & 93.8 & 16.5 & 94.9 & 16.8 & 112.6 & 10.5 & 70.9 & 19.7 & 78.2 \\
\hline & 2015 & 21.3 & 51.3 & 21.2 & 33.7 & 21.9 & 30.1 & 18.7 & 63.6 & 18.9 & 85.7 & 12.8 & 68.4 & 21.8 & 57.4 \\
\hline \multirow{2}{*}{ September } & 2014 & 14.7 & 173.8 & 14.5 & 240.3 & 15.7 & 142.8 & 12.3 & 270.8 & 12.2 & 147.0 & 5.9 & 215.4 & 14.9 & 139.5 \\
\hline & 2015 & 16.1 & 91.2 & 16.0 & 107.2 & 17.7 & 50.7 & 14.4 & 102.2 & 14.5 & 84.3 & 7.8 & 77.8 & 17.6 & 60.2 \\
\hline \multirow{2}{*}{ October } & 2014 & 11.8 & 49.7 & 11.4 & 69.8 & 11.5 & 58.5 & 9.4 & 71.5 & 9.1 & 42.9 & 4.0 & 92.1 & 12.0 & 59.0 \\
\hline & 2015 & 10.9 & 166.6 & 11.0 & 185.6 & 11.6 & 145.8 & 8.8 & 266.2 & 8.4 & 106.9 & 3.0 & 315.4 & 11.1 & 124.6 \\
\hline \multirow{2}{*}{ November } & 2014 & 8.3 & 55.2 & 8.8 & 170.6 & 7.5 & 42.1 & 7.0 & 131.8 & 6.0 & 56.6 & 1.3 & 139.4 & 8.9 & 47.0 \\
\hline & 2015 & 4.5 & 62.5 & 5.0 & 45.2 & 5.2 & 83.0 & 5.4 & 118.0 & 3.4 & 71.2 & 2.5 & 178.4 & 6.0 & 75.1 \\
\hline \multirow[b]{2}{*}{ December } & 2014 & 2.2 & 85.2 & 2.7 & 133.9 & 2.6 & 116.0 & 0.8 & 137.2 & -0.5 & 88.0 & $-4,4$ & 211.1 & 2.7 & 83.4 \\
\hline & 2015 & -1.3 & 0.2 & 0.8 & 0.2 & 0.6 & 0.6 & 1.2 & 2.2 & -1.8 & 0.6 & -0.2 & 1.6 & -0.5 & 2.5 \\
\hline \multirow{2}{*}{$\begin{array}{c}\text { Average year } \\
\text { Tm/ } / \Sigma p t\end{array}$} & 2014 & 11.3 & 1114.4 & 11.3 & 1656.2 & 11.6 & 1133,1 & 9.0 & 1708.2 & 8.8 & 1219,80 & 2.5 & 1772.7 & 11.6 & 1082.7 \\
\hline & 2015 & 10.3 & 808.8 & 10.6 & 819.9 & 11.0 & 866,50 & 8.6 & 1252.8 & 8.0 & 836,50 & 2.7 & 1345.6 & 10.8 & 766.3 \\
\hline
\end{tabular}

* data from Federal Hydrometeorological Service, Sarajevo; ** Republic Hydrometeorological Service Banja Luka;

$\mathrm{Tm}$-mean monthly air temperature $\left({ }^{\circ} \mathrm{C}\right) ; \mathrm{Ppt}$-quantity of rainfall $(\mathrm{mm})$.

Selected locations are the best known and are very important for wild fruit production in B\&H. The fruit was picked in the optimal stage of ripeness for processing (from the end of June to the end of October), which was established based on color (Table 2). Immediately after harvesting, the samples were transported to the laboratory where only undamaged fruit was selected from each location (five independent samples every year), $1 \mathrm{~kg}$ for each wild fruit species. All samples were immediately frozen in liquid nitrogen and kept at a temperature of $-20{ }^{\circ} \mathrm{C}$ until individual sugars and organic acids were analyzed.

Table 2. Sample codes of wild fruit species.

\begin{tabular}{|c|c|c|c|c|}
\hline Genotype & Growing Region & Sample Code & $\begin{array}{l}\text { Harvesting } \\
\text { Time 2014/2015 }\end{array}$ & Color \\
\hline \multirow{4}{*}{$\begin{array}{c}\text { Rosehip } \\
\text { (Rosa canina L.) }\end{array}$} & $\begin{array}{c}\text { Bugojno (altitude }=942 \mathrm{~m} \text { a.s.l. }{ }^{*}, 43^{\circ} 19^{\prime} 23.74^{\prime \prime} \mathrm{N} \\
/ 18^{\circ} 8^{\prime} 16.33^{\prime \prime} \mathrm{E} \text { carbonated brown soil) }\end{array}$ & DRB & 12.10./25.10. & \multirow{4}{*}{ bright red } \\
\hline & $\begin{array}{l}\text { Drvar (altitude }=700 \mathrm{~m} \text { a.s.l., } 44^{\circ} 22^{\prime} 26^{\prime \prime} \mathrm{N} \\
/ 16^{\circ} 22^{\prime} 50.9^{\prime \prime} \mathrm{E} \text { carbonated red soil) }\end{array}$ & DRD & 3.10./5.10. & \\
\hline & $\begin{array}{c}\text { Foča (altitude }=511 \mathrm{~m} \text { a.s.l., } \\
43^{\circ} 35^{\prime} 3^{\prime \prime} \mathrm{N} / 18^{\circ} 47^{\prime} 33^{\prime \prime} \mathrm{E} \text { acidic brown soil) }\end{array}$ & DRF & 30.9./3.10. & \\
\hline & $\begin{array}{c}\text { Konjic (altitude }=975 \mathrm{~m} \text { a.s.l., } 43,83^{\circ} \mathrm{N} / 17,85^{\circ} \mathrm{E} \\
\text { district brown soil) }\end{array}$ & DRK & 9.10./28.10. & \\
\hline \multirow{4}{*}{$\begin{array}{l}\text { Cornelian cherry } \\
\text { (Cornus mas L.) }\end{array}$} & $\begin{array}{c}\text { Bugojno (altitude }=942 \mathrm{~m} \text { a.s.l., } \\
43^{\circ} 19^{\prime} 23.74^{\prime \prime} \mathrm{N} / 18^{\circ} 8^{\prime} 16.33^{\prime \prime} \mathrm{E} \text { carbonated } \\
\text { brown soil) }\end{array}$ & $\mathrm{CCB}$ & 25.9./28.9. & \multirow{4}{*}{ dark red } \\
\hline & $\begin{array}{c}\text { Drvar (altitude }=700 \mathrm{~m} \text { a.s.l., } \\
44^{\circ} 22^{\prime} 26^{\prime \prime} \mathrm{N} / 16^{\circ} 22^{\prime} 50.9^{\prime \prime} \mathrm{E} \text { carbonated red soil) }\end{array}$ & $\mathrm{CCD}$ & 23.9./27.9. & \\
\hline & $\begin{array}{c}\text { Foča (altitude }=511 \mathrm{~m} \text { a.s.l., } \\
43^{\circ} 35^{\prime} 3^{\prime \prime} \mathrm{N} / 18^{\circ} 47^{\prime} 33^{\prime \prime} \mathrm{E} \text { acidic brown soil) }\end{array}$ & $\mathrm{CCF}$ & 15.9./19.9. & \\
\hline & $\begin{array}{c}\text { Konjic (altitude }=750 \mathrm{~m} \text { a.s.l., } \\
43.5807^{\circ} \mathrm{N} / 18.0166^{\circ} \mathrm{E} \text { carbonated brown soil) }\end{array}$ & CCK & 20.9./26.9. & \\
\hline \multirow{2}{*}{$\begin{array}{l}\text { Wild strawberry } \\
\text { (Fragaria vesca L.) }\end{array}$} & $\begin{array}{c}\text { Romanija (altitude }=1024 \text { m a.s.l., } \\
43^{\circ} 52^{\prime} 33.2^{\prime \prime} \mathrm{N} / 18^{\circ} 40^{\prime} 10.92^{\prime \prime} \text { E rendzina) }\end{array}$ & WSR & 20.6./29.6. & \multirow{2}{*}{ red } \\
\hline & $\begin{array}{c}\text { Bjelašnica (altitude }=1430 \mathrm{~m} \text { a.s.l., } \\
43,67^{\circ} \mathrm{N} / 18,23^{\circ} \mathrm{E} \text { rendzina) }\end{array}$ & WSB & 5.7./8.7. & \\
\hline $\begin{array}{c}\text { Bilberry } \\
\text { (Vaccinium myrtillus L.) }\end{array}$ & $\begin{array}{c}\text { Fojnica (altitude }=1670 \mathrm{~m} \text { a.s.l., } \\
43^{\circ} 57^{\prime} 26^{\prime \prime} \mathrm{N} / 17^{\circ} 45^{\prime} 17^{\prime \prime} \mathrm{E} \text { brown acidic soil) }\end{array}$ & WBF & 16.8./24.7. & dark purple \\
\hline
\end{tabular}

* Above sea level. 


\subsection{Standards and Chemicals}

All chemicals, including the standards for sugars and organic acids, were obtained from Sigma-Aldrich (Steinheim, Germany) and Fluka Chemie GmbH (Buchs, Switzerland). All reagents used were of analytical grade of purity.

\subsection{Sugar Extraction and Analysis}

The content of individual sugars (glucose, fructose and sucrose) were analyzed by using a thermal separation technique, i.e., HPLC with a refractive index (RI) detector (Thermo Scientific Finnigan Surveyors ChromQuest 4.0 software). Determination of the content of individual sugars using the HPLC technique was performed according to the Hudina and Stampar [48] method. Ten grams of fresh fruit with bidistilled water totaling a volume of $40 \mathrm{~mL}$ was homogenized by using a mixer (Heidolph Promax 202) and left for $30 \mathrm{~min}$ at a temperature of $24{ }^{\circ} \mathrm{C}$, as described in research by Begić-Akagić et al. [49]. After extraction, homogenized samples were centrifuged for $7 \mathrm{~min}$ at 10,000 rpm at $5{ }^{\circ} \mathrm{C}$ with a centrifuge (Thermo Scientific Sorvall ST16R). The resulting extract was filtered through a $0.45 \mu \mathrm{m}$ cellulose filter (Macherey-Nagel, Düren, Germany), thereby supernatant was obtained, which was transferred directly into vials and used for HPLC analyses of individual sugars and organic acids. Bidistilled water was used to prepare a sugar standard, in order to create a standard curve. The mobile phase (isocratic system) consisted of bidistilled water, while a Hi-Plex Ca column $(300 \times 7.7 \mathrm{~mm}, 8 \mu \mathrm{m}$; Agilent Technologies, Santa Clara, CA, USA) was used to separate the sugars at a temperature of $65^{\circ} \mathrm{C}$, with a flow rate of $0.6 \mathrm{~mL} \mathrm{~min}^{-1}$ for $30 \mathrm{~min}$. Individual sugars were calculated based on their standards and expressed in $\mathrm{g} / \mathrm{kg}$ of fresh mass (FM). The glucose and fructose ratio $(\mathrm{G} / \mathrm{F})$ was calculated from the values of glucose content and fructose content.

\subsection{Organic Acids Extraction and Analysis}

The content of organic acids (malic, citric, shikimic and fumaric) was analyzed using the HPLC technique, with an ultraviolet (UV) detector with a wavelength of $210 \mathrm{~nm}$, according to the Hudina and Stampar [48] method. Sample extraction was performed according to the method already described for sugars. Bidistilled water was used to prepare an organic acid standard, in order to create a standard curve. For separation of organic acids, the Hi-Plex Ca column $(300 \times 7.7 \mathrm{~mm}, 8 \mu \mathrm{m}$; Agilent Technologies, Santa Clara, CA, USA) was used at a temperature of $65^{\circ} \mathrm{C}$, with flow rate of $0.6 \mathrm{~mL} \mathrm{~min}^{-1}$ for $30 \mathrm{~min}$, while the mobile phase consisted of $4 \mathrm{mM}$ sulfuric acid. Content of individual acids was calculated based on the acid standards and expressed in $\mathrm{g} / \mathrm{kg}$ of fresh mass (FM). The content of total organic acids was obtained by summing the data of individual components, and values of total sugar content and total organic acids content were used to calculate the sugar/organic acid ratio (S/A).

\subsection{Statistical Analysis}

Statistical data processing was performed by using Statgraph 3.14 and SPSS 20 programs. The influence of location and growing year for wild fruit species on content of individual and total sugars and organic acids, as well as S/A and G/F ratios, was analyzed by using two-factor analysis of variance (ANOVA), with the exception of bilberry, where influence of growing year on the parameters noted was tested. The established differences of mean values were tested by Tukey's test. PCA analysis was used to identify the differentiation factor of wild fruit species from different locations based on analyzed chemical properties (content of individual and total sugars and organic acids, S/A and G/F ratios). For PCA analysis, mean values per year were used. In order to establish the connection of analyzed parameters of wild fruit species quality with environmental factors, Pearson's correlation coefficient values were calculated by using the SPSS 20 program. 


\section{Results and Discussion}

\subsection{Content of Total and Individual Sugars}

The content of total and individual sugars in wild fruit species (rosehip, cornelian cherry, wild strawberry and bilberry) originating from different locations in B\&H (Bugojno, Drvar, Foča, Konjic, Romanija, Bjelašnica, Fojnica) is presented in Table 3. A significant influence of location and growing year was established (Table 3), as well as their interaction within the same fruit species (rosehip, cornelian cherry and wild strawberry), i.e., in bilberry, the year of growth on the content of individual and total sugars and G/F ratio. The exceptions were glucose and total sugars in rosehip fruits and fructose in strawberry, where no interaction of experimental factors was established, and G/F ratio in rosehip, where significant differences were not established for growing year. Fructose was predominantly present in analyzed wild fruit species, followed by glucose, while sucrose content was lowest, probably due to high invertase activity in the final ripening stage. This ratio of fructose and glucose in fruit is of particular importance for patients with diabetes, since it maintains the consistency of sugar in blood [50]. Given that the lowest sucrose content was observed in bilberry $\left(1.35 \mathrm{~g} \mathrm{~kg}^{-1}\right)$ in 2015 , this fruit should be promoted in a low-sugar diet. Montesano and collaborators [51] reported in all analyzed goji fruits that sucrose content was about ten times lower than each mannose. In analyzed wild fruit, G/F ratio ranged from 0.80 to 0.99 , except for wild strawberry samples where this ratio was very low, ranging from 0.35 to 0.51 (Table 3). Such low values of G/F ratio were the result of higher acids content in wild strawberry and not microbial damage. Namely, according to European Fruit Juice Association (AIJN) recommendations [37], strawberry juice with G/F ratio below 0.75 is the indicator of microbial damage.

Table 3. Average content of individual sugars, total sugars (TS) and glucose/fructose ratio $(\mathrm{G} / \mathrm{F}) \pm \mathrm{SE}$ in analyzed wild fruit species ( $\mathrm{g} \mathrm{kg}^{-1} \mathrm{FM}$ (fresh mass)) *.

\begin{tabular}{|c|c|c|c|c|c|c|c|c|c|c|c|}
\hline \multirow{2}{*}{$\begin{array}{c}\text { Species/Growing } \\
\text { Region }\end{array}$} & \multirow{2}{*}{ Growing Season } & \multicolumn{2}{|c|}{ Glucose } & \multicolumn{2}{|c|}{ Fructose } & \multicolumn{2}{|c|}{ Sucrose } & \multicolumn{2}{|c|}{ TS } & \multicolumn{2}{|c|}{$\mathrm{G} / \mathrm{F}$} \\
\hline & & $x^{-}$ & SE & $x^{-}$ & SE & $x^{-}$ & SE & $x^{-}$ & SE & $x^{-}$ & SE \\
\hline \multirow{2}{*}{ DRB } & 2014 & 70.78 & $1.777 x$ & 84.66 & $2.317 x$ & 4.66 & $0.234 x$ & 160.11 & $2.166 x$ & 0.84 & 0.027 \\
\hline & 2015 & 65.51 & $0.658 \mathrm{y}$ & 78.53 & $0.396 y$ & 3.98 & $0.019 \mathrm{y}$ & 148.02 & $0.970 \mathrm{y}$ & 0.83 & 0.007 \\
\hline \multicolumn{2}{|c|}{ Mean by region } & 68.15 & $3.126 b$ & 81.60 & $3.471 b$ & 4.32 & $0.399 b$ & 154.06 & $6.787 b$ & 0.84 & $0.018 c$ \\
\hline \multirow{2}{*}{ DRD } & 2014 & 80.38 & 1.455 & 91.45 & $1.091 \mathrm{x}$ & 5.47 & $0.456 x$ & 177.31 & $0.276 x$ & 0.88 & 0.026 \\
\hline & 2015 & 74.01 & 0.735 & 86.96 & $1.123 y$ & 4.63 & $0.027 y$ & 165.60 & $0.236 y$ & 0.85 & 0.002 \\
\hline \multicolumn{2}{|c|}{ Mean by region } & 77.19 & $4.610 a$ & 89.20 & $2.557 a$ & 5.05 & $0.546 a$ & 171.45 & $6.417 a$ & 0.87 & $0.023 b$ \\
\hline \multirow{2}{*}{ DRF } & 2014 & 78.96 & 0.619 & 92.68 & $1.287 x$ & 6.12 & 0.294 & 177.77 & $2.146 x$ & 0.85 & 0.007 \\
\hline & 2015 & 73.28 & 0.773 & 86.62 & $0.360 \mathrm{y}$ & 4.30 & 0.012 & 164.20 & $0.910 \mathrm{y}$ & 0.85 & 0.002 \\
\hline \multicolumn{2}{|c|}{ Mean by region } & 76.12 & $2.173 a$ & 89.65 & $3.428 a$ & 5.21 & $1.013 a$ & 170.99 & $7.574 a$ & 0.85 & $0.008 b c$ \\
\hline \multirow{2}{*}{ DRK } & 2014 & 70.89 & 0.959 & 78.84 & $0.793 x$ & 4.18 & 0.151 & 153.92 & $1.213 x$ & 0.90 & 0.017 \\
\hline & 2015 & 66.07 & 0.059 & 69.33 & $1.481 \mathrm{y}$ & 3.05 & 0.047 & 138.44 & $0.484 y$ & 0.95 & 0.006 \\
\hline \multicolumn{2}{|c|}{ Mean by region } & 68.48 & $2.712 b$ & 74.09 & $5.244 c$ & 3.61 & $0.629 c$ & 146.18 & $8.516 \mathrm{c}$ & 0.93 & $0.032 a$ \\
\hline \multirow[t]{2}{*}{$\mathrm{CCB}$} & 2014 & 74.61 & $1.437 x$ & 81.44 & $0.800 \mathrm{x}$ & 4.03 & $0.181 x$ & 160.08 & $0.726 x$ & 0.92 & $0.026 x$ \\
\hline & 2015 & 67.78 & $0.420 \mathrm{y}$ & 71.21 & $0.251 \mathrm{y}$ & 2.62 & $0.060 \mathrm{y}$ & 141.61 & $0.443 y$ & 0.95 & $0.007 \mathrm{y}$ \\
\hline \multicolumn{2}{|c|}{ Mean by region } & 71.19 & $3.856 a$ & 76.33 & $5.629 c$ & 3.33 & $0.786 b$ & 150.85 & $10.134 b$ & 0.93 & $0.026 a$ \\
\hline \multirow[t]{2}{*}{$\mathrm{CCD}$} & 2014 & 75.90 & $0.784 x$ & 82.11 & $0.411 \mathrm{x}$ & 3.79 & $0.256 x$ & 161.79 & $0.354 x$ & 0.92 & $0.013 x$ \\
\hline & 2015 & 62.49 & $0.873 y$ & 71.64 & $0.307 \mathrm{y}$ & 2.89 & $0.088 \mathrm{y}$ & 137.03 & $1.218 \mathrm{y}$ & 0.87 & $0.009 y$ \\
\hline \multicolumn{2}{|c|}{ Mean by region } & 69.19 & $7.380 \mathrm{~b}$ & 76.87 & $5.74 b c$ & 3.34 & $0.521 b$ & 149.41 & $13.589 b$ & 0.90 & $0.03 b$ \\
\hline \multirow[t]{2}{*}{$\mathrm{CCF}$} & 2014 & 71.90 & $1.607 x$ & 84.18 & $1.510 \mathrm{x}$ & 4.84 & $0.332 x$ & 160.93. & $2.675 x$ & 0.85 & $0.013 x$ \\
\hline & 2015 & 66.04 & $0.141 \mathrm{y}$ & 78.80 & $0.319 \mathrm{y}$ & 3.17 & $0.007 y$ & 148.01 & $0.432 \mathrm{y}$ & 0.84 & $0.003 y$ \\
\hline \multicolumn{2}{|c|}{ Mean by region } & 68.97 & $3.370 b$ & 81.49 & $3.103 a$ & 4.00 & $0.938 a$ & 154.47 & $7.276 a$ & 0.85 & $0.012 c$ \\
\hline \multirow{2}{*}{ CCK } & 2014 & 70.32 & $1.039 x$ & 80.62 & $1.276 \mathrm{x}$ & 3.42 & $0.106 x$ & 154.36 & $2.322 x$ & 0.87 & $0.002 x$ \\
\hline & 2015 & 60.04 & $0.053 \mathrm{y}$ & 74.86 & $0.084 y$ & 2.72 & $0.105 y$ & 137.61 & $0.186 y$ & 0.80 & $0.001 \mathrm{y}$ \\
\hline \multicolumn{2}{|c|}{ Mean by region } & 65.18 & $5.667 c$ & 77.74 & $3.26 b$ & 3.07 & $0.398 b$ & 145.99 & $9.292 \mathrm{c}$ & 0.84 & $0.034 c$ \\
\hline \multirow[t]{2}{*}{ WSB } & 2014 & 24.54 & $1.170 \mathrm{x}$ & 62.83 & $1.637 x$ & 5.18 & $0.172 x$ & 92.55 & $0.468 x$ & 0.39 & $0.029 x$ \\
\hline & 2015 & 18.50 & $0.383 y$ & 52.71 & $1.089 \mathrm{y}$ & 4.70 & $0.007 \mathrm{y}$ & 75.92 & $1.363 y$ & 0.35 & $0.006 y$ \\
\hline \multicolumn{2}{|c|}{ Mean by region } & 21.52 & $3.398 b$ & 57.77 & $5.682 b$ & 4.94 & $0.280 b$ & 84.23 & $9.156 b$ & 0.37 & $0.029 b$ \\
\hline \multirow[t]{2}{*}{ WSR } & 2014 & 35.43 & $1.030 \mathrm{x}$ & 69.30 & $0.736 x$ & 6.84 & $0.134 x$ & 111.56 & $1.047 x$ & 0.51 & $0.017 x$ \\
\hline & 2015 & 22.60 & $0.300 \mathrm{y}$ & 58.34 & $0.458 \mathrm{y}$ & 5.94 & $0.186 y$ & 86.87 & $0.276 y$ & 0.39 & $0.008 \mathrm{y}$ \\
\hline Mean & region & 29.01 & $7.060 a$ & 63.82 & $6.025 a$ & 6.00 & $1.332 a$ & 99.22 & $13.539 a$ & 0.45 & $0.069 a$ \\
\hline WBF & 2014 & 34.40 & $0.587 x$ & 36.49 & $1.126 x$ & 2.86 & $0.130 x$ & 73.75 & $1.794 \mathrm{x}$ & 0.94 & 0.016 \\
\hline & 2015 & 27.98 & $0.856 y$ & 28.22 & $1.048 \mathrm{y}$ & 1.35 & $0.120 \mathrm{y}$ & 57.55 & $1.787 \mathrm{y}$ & 0.99 & 0.031 \\
\hline Mean & y year & 31.19 & 3.573 & 32.35 & 4.631 & 2.11 & 0.838 & 65.65 & 9.014 & 0.97 & 0.035 \\
\hline
\end{tabular}

* Average values \pm standard error (SE) in column marked with different letters $(\mathrm{a}-\mathrm{c})$ represent statistically significant differences between locations within the same species; different letters $(x-y)$ represent statistically significant differences between growing year of wild fruit; Tukey's test, $p<0.05$. 
In general, content of individual and total sugars and G/F ratio were higher in 2014 than in 2015. The reason for the difference was probably higher average temperature, as well as the amount of precipitation in 2014 in comparison to 2015. On the other hand, by comparing growing regions, it can be clearly seen that the concentrations of mentioned components were higher, e.g., for the Foča region in relation to Konjic concerning rosehip and cornelian cherry and for the Romanija region in relation to Bjelašnica concerning wild strawberry. This could be a consequence of higher average temperatures, higher amounts of precipitation and lower altitudes in comparison to the other analyzed locations (Table 1). As is presented in Table 3, the content of total sugars in analyzed wild fruit was the lowest in bilberry $\left(57.55 \mathrm{~g} \mathrm{~kg}^{-1}\right)$ in 2015 , and the highest was in rosehip from the Foča location in $2014\left(177.77 \mathrm{~g} \mathrm{~kg}^{-1}\right)$. Within the frame of the same species, the lowest content of total sugars was observed in samples from the Konjic location $\left(138.44 \mathrm{~g} \mathrm{~kg}^{-1}\right)$ in 2015. Depending on fruit species, but also location and growing year, the content of total sugars changed. According to Rosu et al. [52], the total sugar content in rosehip was $132.8 \mathrm{~g} \mathrm{~kg}^{-1}$ in the northeastern region of Romania, and ranged from 133.4 to $171.4 \mathrm{~g} \mathrm{~kg}^{-1}$ for different regions in Iran [53], which is in accordance with the results reported here. However, the values obtained were lower in comparison with results of Barros et al. [54], where sugar content in rosehip was $293.2 \mathrm{~g} \mathrm{~kg}^{-1}$.

In the research of Tural and Koca [55] and Bijelić et al. [56], the total sugar content in cornelian cherry ranged from 76.80 to $154.00 \mathrm{~g} \mathrm{~kg}^{-1}$ and 134.9 and $252.4 \mathrm{~g} \mathrm{~kg}^{-1}$, respectively, which is in accordance with results of the conducted experiment. However, Drkenda et al. [47] established lower total sugar content in cornelian cherry $\left(62.46-85.20 \mathrm{~g} \mathrm{~kg}^{-1}\right)$. The established differences in total sugar content in cornelian cherry may be a consequence of the amount of precipitation and average temperature during vegetation, as well as type of soil. Therefore, according to Leeuwen et al., [57], climate and soil conditions showed higher impact on the chemical content of fruit in relation to species and cultivar. Values obtained for total sugar content in wild strawberry were lower $\left(75.92-111.56 \mathrm{~g} \mathrm{~kg}^{-1}\right)$ in comparison with Milivojević et al. [40], where total sugar content in wild strawberry was $209.4 \mathrm{~g} \mathrm{~kg}^{-1}$. In addition, lower sugar content was observed in bilberry $\left(57.55 \mathrm{~g} \mathrm{~kg}^{-1}\right.$ in 2015 and $73.75 \mathrm{~g} \mathrm{~kg}^{-1}$ in 2014), in comparison with Milivojević et al. [9] and Milivojević et al. [40]. On the other hand, results obtained for bilberry were in accordance with results obtained by Stajčić et al. [10] and Viljakainen et al. [58], where total sugar content was $78.4 \mathrm{~g} \mathrm{~kg}^{-1}$ and $72.94 \mathrm{~g} \mathrm{~L}^{-1}$ for juice. Lower sugar content in analyzed samples, Romanija wild strawberry (WSR), Bjelašnica wild strawberry (WSB) and Fojnica bilberry (WBF), was followed by higher acid content (Table 4). Therefore, deviations occurring in sugar content compared to the reference data presented appear to be likely caused by differences in location altitudes where the samples were collected, as well as agroecological conditions.

Table 4. Average content of individual organic acids, total acids (TA) and sugars/acids ratio (S/A) in analyzed wild fruit species $\left(\mathrm{g} \mathrm{kg}^{-1} \mathrm{FM}\right)$ *

\begin{tabular}{|c|c|c|c|c|c|c|c|c|c|c|c|c|c|}
\hline \multirow{2}{*}{$\begin{array}{c}\text { Species/Growing } \\
\text { Region }\end{array}$} & \multirow{2}{*}{$\begin{array}{l}\text { Growing } \\
\text { Season }\end{array}$} & \multicolumn{2}{|c|}{ Malic Acid } & \multicolumn{2}{|c|}{ Citric Acid } & \multicolumn{2}{|c|}{ Shikimic Acid } & \multicolumn{2}{|c|}{ Fumaric Acid } & \multicolumn{2}{|c|}{ TA } & \multicolumn{2}{|c|}{ S/A } \\
\hline & & $\mathrm{x}^{-}$ & SE & $\mathrm{x}^{-}$ & SE & $x^{-}$ & SE & $x^{-}$ & SE & $x^{-}$ & SE & $x^{-}$ & SE \\
\hline \multirow[b]{2}{*}{ DRB } & 2014 & 4.09 & $0.124 x$ & 1.57 & $0.114 x$ & 0.33 & $0.042 x$ & 0.07 & $0.006 x$ & 6.07 & $0.253 x$ & 26.42 & $1.161 \mathrm{x}$ \\
\hline & 2015 & 5.87 & $0.057 \mathrm{y}$ & 1.96 & $0.910 \mathrm{y}$ & 0.43 & $0.043 y$ & 0.09 & $0.007 y$ & 8.35 & $0.015 y$ & 17.73 & $0.084 y$ \\
\hline \multicolumn{2}{|c|}{ Mean by region } & 4.98 & $1.230 \mathrm{c}$ & 1.76 & $1.023 c$ & 0.38 & $0.066 d$ & 0.08 & $0.013 c$ & 7.21 & $1.260 c$ & 22.07 & $4.816 b$ \\
\hline \multirow{2}{*}{ DRD } & 2014 & 6.43 & $0.223 x$ & 2.06 & $0.161 \mathrm{x}$ & 0.52 & $0.042 x$ & 0.25 & $0.025 x$ & 9.26 & $0.202 x$ & 19.16 & $0.424 x$ \\
\hline & 2015 & 7.27 & $0.183 y$ & 2.27 & $0.987 y$ & 0.78 & $0.009 y$ & 0.34 & $0.008 y$ & 10.66 & $0.453 y$ & 15.55 & $0.662 y$ \\
\hline \multicolumn{2}{|c|}{ Mean by region } & 6.85 & $0.493 b$ & 2.16 & $0.560 b$ & 0.65 & $0.146 b$ & 0.29 & $0.051 a$ & 9.96 & $0.830 b$ & 17.36 & $2.038 \mathrm{c}$ \\
\hline \multirow{2}{*}{ DRF } & 2014 & 3.87 & $0.098 \mathrm{x}$ & 1.48 & $0.024 \mathrm{x}$ & 0.44 & $0.028 \mathrm{x}$ & 0.07 & $0.003 x$ & 5.87 & $0.079 \mathrm{x}$ & 30.28 & $0.113 x$ \\
\hline & 2015 & 5.11 & $0.075 y$ & 1.80 & $0.005 y$ & 0.53 & $0.004 y$ & 0.08 & $0.001 y$ & 7.51 & $0.080 \mathrm{y}$ & 21.86 & $0.177 \mathrm{y}$ \\
\hline \multicolumn{2}{|c|}{ Mean by region } & 4.49 & $1.679 d$ & 1.64 & $0.210 c$ & 0.49 & $0.049 \mathrm{c}$ & 0.08 & $0.010 c$ & 6.69 & $0.902 d$ & 26.07 & $4.616 a$ \\
\hline \multirow{2}{*}{ DRK } & 2014 & 7.35 & $0.184 \mathrm{x}$ & 2.78 & $0.117 x$ & 0.71 & $0.034 x$ & 0.12 & $0.024 x$ & 10.96 & $0.318 \mathrm{x}$ & 14.06 & $0.462 x$ \\
\hline & 2015 & 8.55 & $1.567 \mathrm{y}$ & 3.18 & $0.155 y$ & 0.84 & $0.031 y$ & 0.18 & $0.069 y$ & 12.74 & $0.369 \mathrm{y}$ & 10.87 & $0.346 y$ \\
\hline \multicolumn{2}{|c|}{ Mean by region } & 7.95 & $3.093 a$ & 2.98 & $0.340 a$ & 0.77 & $0.078 a$ & 0.15 & $0.057 b$ & 11.85 & $1.027 a$ & 12.46 & $1.78 d$ \\
\hline
\end{tabular}


Table 4. Cont

\begin{tabular}{|c|c|c|c|c|c|c|c|c|c|c|c|c|c|}
\hline \multirow{2}{*}{$\begin{array}{c}\text { Species/Growing } \\
\text { Region }\end{array}$} & \multirow{2}{*}{$\begin{array}{l}\text { Growing } \\
\text { Season }\end{array}$} & \multicolumn{2}{|c|}{ Malic Acid } & \multicolumn{2}{|c|}{ Citric Acid } & \multicolumn{2}{|c|}{ Shikimic Acid } & \multicolumn{2}{|c|}{ Fumaric Acid } & \multicolumn{2}{|c|}{ TA } & \multicolumn{2}{|c|}{ S/A } \\
\hline & & $\mathrm{x}^{-}$ & SE & $x^{-}$ & SE & $\mathrm{x}^{-}$ & SE & $x^{-}$ & SE & $x^{-}$ & SE & $x^{-}$ & SE \\
\hline \multirow[t]{2}{*}{$\mathrm{CCB}$} & 2014 & 28.61 & $0.863 x$ & 1.30 & $0.044 x$ & 0.57 & $0.121 x$ & 0.50 & $0.060 \mathrm{x}$ & 30.97 & $0.832 y$ & 5.17 & $0.126 x$ \\
\hline & 2015 & 31.43 & $0.582 y$ & 1.49 & $0.098 \mathrm{y}$ & 0.83 & $0.013 \mathrm{y}$ & 0.59 & $0.02 \mathrm{y}$ & 34.34 & $0.532 x$ & 4.12 & $0.075 y$ \\
\hline \multicolumn{2}{|c|}{ Mean by region } & 30.02 & $1.681 b$ & 1.40 & $0.124 a$ & 0.70 & $0.158 b$ & 0.55 & $0.066 b$ & 32.66 & $1.945 b$ & 4.65 & $0.580 b$ \\
\hline \multirow[t]{2}{*}{$\mathrm{CCD}$} & 2014 & 30.81 & $1.929 x$ & 1.43 & $0.039 x$ & 1.18 & $0.242 x$ & 1.01 & $0.079 x$ & 34.43 & $1.687 \mathrm{y}$ & 4.71 & $0.218 \mathrm{x}$ \\
\hline & 2015 & 34.06 & $1.102 \mathrm{y}$ & 1.54 & $0.067 \mathrm{y}$ & 1.45 & $0.386 \mathrm{y}$ & 1.12 & $0.036 \mathrm{y}$ & 38.17 & $0.804 \mathrm{x}$ & 3.59 & $0.066 \mathrm{y}$ \\
\hline \multicolumn{2}{|c|}{ Mean by region } & 32.44 & $2.269 a$ & 1.48 & $0.080 a$ & 1.31 & $0.322 a$ & 1.07 & $0.082 a$ & 36.30 & $2.365 a$ & 4.15 & $0.628 c$ \\
\hline \multirow{2}{*}{$\mathrm{CCF}$} & 2014 & 24.98 & $0.884 \mathrm{x}$ & 1.13 & $0.112 x$ & 0.51 & $0.028 x$ & 0.36 & $0.015 x$ & 26.99 & $0.794 y$ & 5.96 & $0.098 \mathrm{x}$ \\
\hline & 2015 & 28.31 & $0.457 \mathrm{y}$ & 1.30 & $0.145 y$ & 0.73 & $0.009 y$ & 0.42 & $0.007 y$ & 30.76 & $0.400 x$ & 4.81 & $0.051 \mathrm{y}$ \\
\hline \multicolumn{2}{|c|}{ Mean by region } & 26.65 & $1.931 c$ & 1.22 & $0.135 b$ & 0.62 & $0.118 b$ & 0.39 & $0.037 b$ & 28.88 & $2.140 c$ & 5.39 & $0.635 a$ \\
\hline \multirow[t]{2}{*}{$\mathrm{CCK}$} & 2014 & 31.13 & $0.938 x$ & 1.43 & $0.171 \mathrm{x}$ & 0.73 & $0.041 x$ & 1.02 & $0.109 x$ & 34.31 & $0.662 y$ & 4.50 & $0.086 x$ \\
\hline & 2015 & 33.39 & $0.564 \mathrm{y}$ & 1.63 & $0.088 \mathrm{y}$ & 0.96 & $0.013 y$ & 1.19 & $0.302 y$ & 37.17 & $0.935 x$ & 3.70 & $0.092 \mathrm{y}$ \\
\hline \multicolumn{2}{|c|}{ Mean by region } & 32.26 & $2.034 a$ & 1.53 & $0.163 a$ & 0.85 & $0.128 b$ & 1.10 & $0.223 a$ & 35.74 & $1.725 a$ & 4.10 & $0.443 c$ \\
\hline \multirow[t]{2}{*}{ WSB } & 2014 & 1.19 & $0.011 y$ & 4.70 & $0.407 y$ & 0.08 & $0.010 \mathrm{y}$ & 0.001 & 0.0001 & 5.97 & $0.396 y$ & 15.55 & $1.124 x$ \\
\hline & 2015 & 2.13 & $0.023 x$ & 6.97 & $0.115 x$ & 0.12 & $0.014 x$ & 0.002 & 0.0001 & 9.22 & $0.094 \mathrm{y}$ & 8.23 & $0.172 \mathrm{y}$ \\
\hline \multicolumn{2}{|c|}{ Mean by region } & 1.66 & $0.518 b$ & 5.83 & $1.271 a$ & 0.10 & 0.022 & 0.002 & 0.0002 & 7.60 & $1.799 a$ & 11.89 & $4.07 b$ \\
\hline \multirow[t]{2}{*}{ WSR } & 2014 & 1.23 & $0.103 y$ & 3.21 & $0.102 y$ & 0.09 & $0.008 y$ & 0.002 & 0.0005 & 4.53 & $0.178 y$ & 24.64 & $1.20 \mathrm{x}$ \\
\hline & 2015 & 2.68 & $0.042 x$ & 6.07 & $0.042 \mathrm{x}$ & 0.11 & $0.002 x$ & 0.002 & 0.0006 & 8.86 & $0.075 x$ & 9.91 & $0.073 y$ \\
\hline \multicolumn{2}{|c|}{ Mean by region } & 1.95 & $1.123 a$ & 4.64 & $1.57 b$ & 0.10 & 0.011 & 0.002 & 0.0005 & 6.70 & $2.37 b$ & 17.22 & $5.159 a$ \\
\hline \multirow[t]{2}{*}{ WBF } & 2014 & 2.56 & $0.250 \mathrm{y}$ & 7.07 & $0.237 y$ & 0.14 & $0.013 y$ & 0.0010 & $0.0002 y$ & 9.78 & $0.471 y$ & 7.55 & $0.317 x$ \\
\hline & 2015 & 4.35 & $0.145 x$ & 10.63 & $0.262 x$ & 0.18 & $0.007 x$ & 0.0014 & $0.0000 x$ & 15.16 & $0.254 x$ & 3.80 & $0.183 y$ \\
\hline \multicolumn{2}{|c|}{ Mean by year } & 3.45 & 1.340 & 8.85 & 1.96 & 0.16 & 0.022 & 0.001 & 0.0003 & 12.47 & 2.968 & 5.67 & 2.068 \\
\hline
\end{tabular}

Average values \pm standard error (SE) in column marked with different letters $(\mathrm{a}-\mathrm{c})$ represent statistically significant differences between locations within the same species; different letters $(x-y)$ represent statistically significant differences between growing year of wild fruit; Tukey's test, $p<0.05$.

\subsection{Content of Total and Individual Organic Acids}

Statistical analysis established significant influence of location and growing year as well as their interaction within the same fruit species, and in bilberry the influence of growing year on the content of total and individual organic acids, and S/A ratio. The exception was fumaric acid in wild strawberry, where no influence of analyzed experimental factors was determined, and only growing year had significant influence on shikimic acid within the same fruit species. The interaction of experimental factors did not affect the above-mentioned components in cornelian cherry, citric, fumaric and total acids in rosehip or shikimic and fumaric acids in strawberry fruit (Table 4). The reason for these observations was lower temperatures and lower amount of precipitation in 2015 (Table 2), as well as the higher altitude of growing regions in Konjic $(975 \mathrm{~m})$ and Bjelašnica $(1430 \mathrm{~m})$ (Table 1). The total acid content in analyzed fruit species ranged from $4.53 \mathrm{~g} \mathrm{~kg}^{-1}$ for wild strawberry from the Romanija location in 2014 and up to $38.17 \mathrm{~g} \mathrm{~kg}^{-1}$ for cornelian cherry in 2015 from the Drvar location.

The statistically significant highest content of total organic acids was observed in cornelian cherry from the Drvar and Konjic locations (36.30 and $35.74 \mathrm{~g} \mathrm{~kg}^{-1}$ ), followed by cornelian cherry from Bugojno (32.66 $\mathrm{g} \mathrm{kg}^{-1}$ ), and the Foča locations having the statistically significant lowest content $\left(28.88 \mathrm{~g} \mathrm{~kg}^{-1}\right)$. These results are in accordance with Begic-Akagic et al. [19], who analyzed influence of location (Goražde, Višegrad and Konjic) on individual organic acid content in cornelian cherry, and total acid content was in the range from $36.6 \mathrm{~g} \mathrm{~kg}^{-1}$ (Drvar) to $48.4 \mathrm{~g} \mathrm{~kg}^{-1}$ (Višegrad). It is presumable that somewhat lower organic acid content present in cornelian cherry from the Foča location was a consequence of climate conditions during the growing season, i.e., higher average temperature $\left(11-11.6^{\circ} \mathrm{C}\right)$ for both the growing years analyzed, in relation to other analyzed locations (Table 1). The lowest total acid content was observed in wild strawberry, which was from $4.53 \mathrm{~g} \mathrm{~kg}^{-1}$ for the Romanija location in 2014 up to $9.22 \mathrm{~g} \mathrm{~kg}^{-1}$ at the Bjelašnica location in growing year 2015. Low organic acid content was also detected in rosehip, which ranged from $5.87 \mathrm{~g} \mathrm{~kg}^{-1}$ for samples from the Foča location in 2014 up to $12.74 \mathrm{~g} \mathrm{~kg}^{-1}$ from the Fojnica location in 2015. Total organic acid content in bilberry was statistically significantly lower in 2014 in comparison to 2015, and it was 9.78 compared to $15.16 \mathrm{~g} \mathrm{~kg}^{-1}$ (Table 4). Demir and Özcan [59] established varying organic acid content in rosehip from different locations in Turkey. Thus, for samples from the Konya (Hadim) location, the acid content expressed as malic acid was $11.7 \mathrm{~g} \mathrm{~kg}^{-1}$, and it was $14.4 \mathrm{~g} \mathrm{~kg}^{-1}$ from the Kastamon location, which is in accordance with the results of the conducted experiment. As per Güneş et al. [23], titratable acidity expressed as citric acid in rosehip was in the range from 11.1 to $36.7 \mathrm{~g} \mathrm{~kg}^{-1}$ and 
influenced by harvesting time. According to Milivojević et al. [40], the total organic acid content was $0.313 \mathrm{mg}(100 \mathrm{~g})^{-1}$ for wild strawberries, which is significantly lower than results of the conducted research (4.53 $\mathrm{g} \mathrm{kg}^{-1}$ at the Romanija location in 2014 and $9.22 \mathrm{~g} \mathrm{~kg}^{-1}$ at the Bjelašnica location in 2015). Differences observed in organic acid content may be the consequence of location altitude where wild fruit samples were collected, as previously reported by Mikulic Petkovsek et al. [60]. Bilberry fruits from high altitude had more organic acid content compared with bilberry fruit from low altitude. Namely, in the conducted research, wild strawberry was collected from the Romanija location (altitude: $1024 \mathrm{~m}$ a.s.l.) and Bjelašnica (1430 m a.s.l.), while according to Milivojević et al. [40], strawberry samples used in the experiment were gathered from locations where the altitude is $350 \mathrm{~m}$ a.s.l. According to Mikulic Petkovsek et al. [60], who investigated the content of sugars, organic acids and phenols of 25 genotypes of wild and cultivated fruit in the area of Slovenia, slightly lower concentrations of citric acid and slightly higher concentrations of malic acid (5.7 and $2.71 \mathrm{~g} \mathrm{~kg}^{-1}$ ) were established in wild blueberries, compared to results of the conducted research $\left(7.07\right.$ and $2.56 \mathrm{~g} \mathrm{~kg}^{-1}$ in year of growth 2014). The analyzed berries had a higher total acid content but also lower sugar content (Table 3) compared to reference data, which may be a result of altitude and stage of ripeness, as well as the climate and soil conditions of the environment $[23,57,61,62]$. The taste and aroma of fruit is directly influenced by S/A ratio. However, the sweet taste of fruit does not always mean higher sugar content, but it is certainly a result of low organic acid content [63]. The highest S/A ratio was recorded in rosehip (30.28) from the Foča location in 2014, and the lowest in cornelian cherry (3.59) in 2015 from the Drvar region. The differences were obvious also amongst locations of rosehip, so the highest S/A ratio was recorded on samples from the Foča location (26.07), followed by Bugojno rosehip (DRB; 22.07), Drvar rosehip (DRD; 17.36) and the significantly lower ratio of the Konjic rosehip sample (DRK; 12.46). Higher S/A ratio was also recorded for wild strawberry in the year 2014 for both locations (15.55 and 24.64). S/A ratio in remaining analyzed samples ranged from 3.59 to 9.01 , and it fell under the group of fruit with sweet-sour or sour-sweet taste. The fruit with lower S/A ratio is used for consumption by households [60], and it is mainly processed into a series of highly valuable products such as juices, jams and marmalades [49]. Based on the results obtained, rosehip fruits with higher S/A are recommended for production of "pekmez" [64] and drying, while genotypes of cornelian cherry, wild strawberry and bilberry, with lower S/A, are recommended for the production of juices and gelatin products.

\subsection{PCA}

According to the results of principal component analysis (PCA), the variability of experiments is explained by three principal components, with $95.9 \%$ of total variability, and with components 1 and 2 explaining $84.9 \%$ of variability (Figure 1 ).

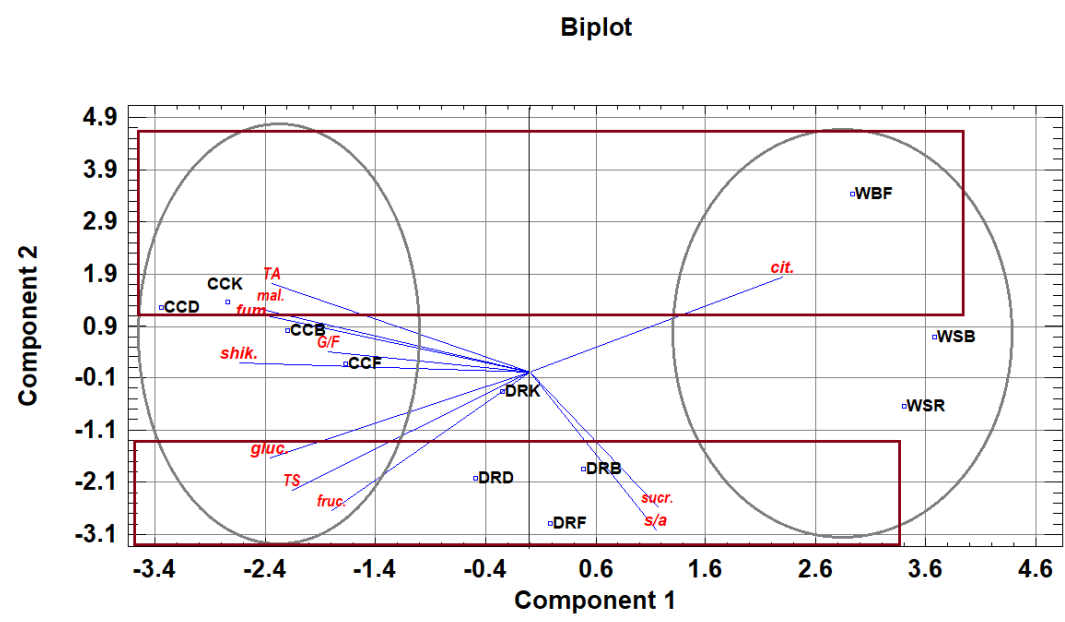

(a)

Figure 1. Cont. 


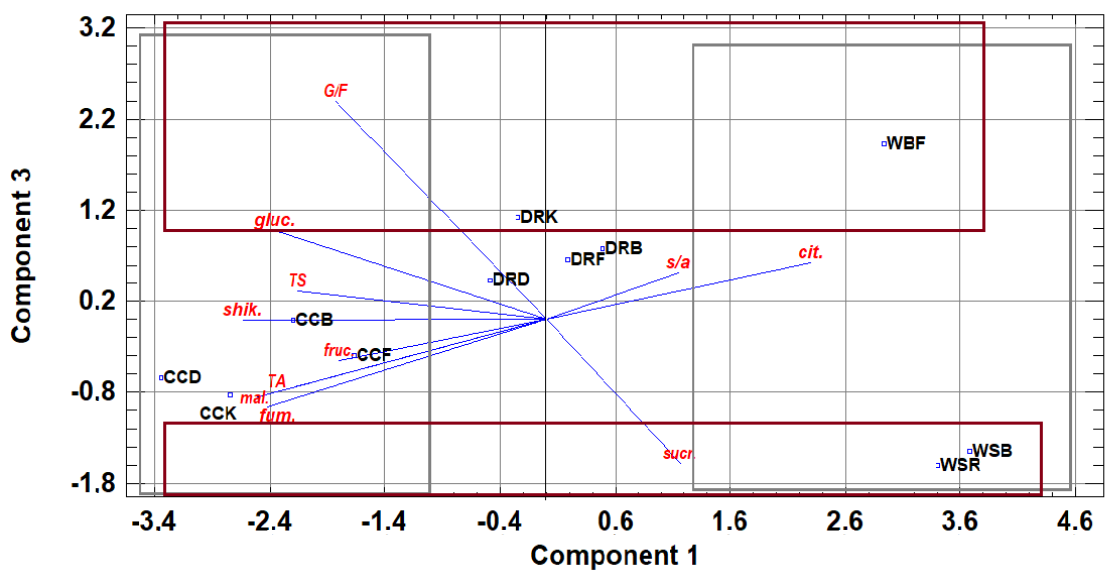

(b)

Biplot

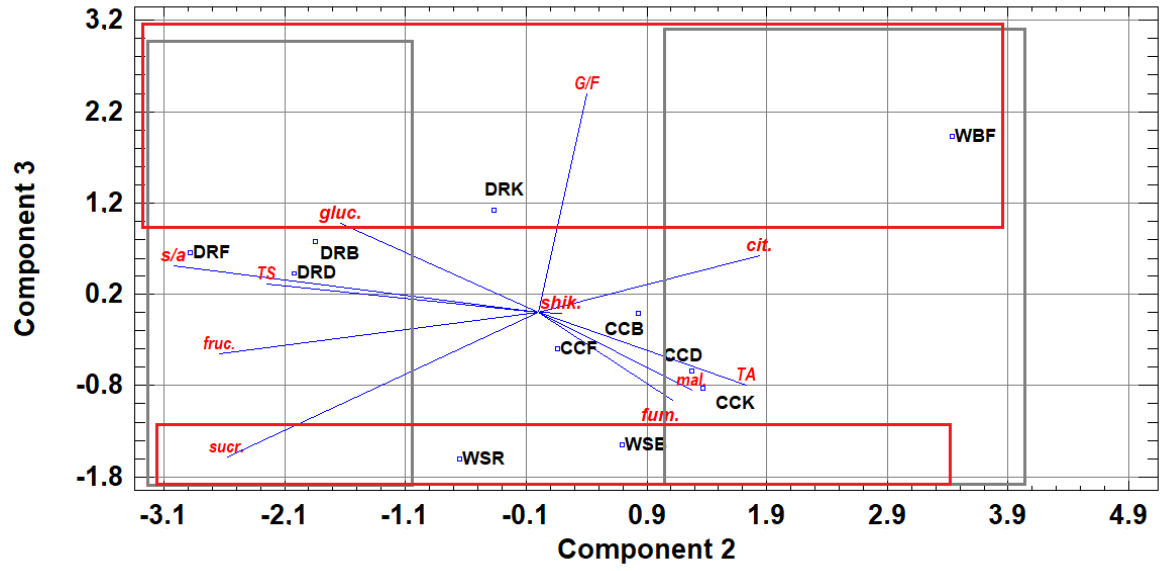

(c)

Figure 1. Principal component analysis (PCA) plots presenting graphical representation of the position of the analyzed wild fruit species from different growing regions (DRB, DRD, DRF, DRK-rosehip from Bugojno, Drvar, Foča and Konjic locations; CCB, CCD, CCF, CCK—cornelian cherry from Bugojno, Drvar, Foča and Konjic locations; WSR, WSB — wild strawberry from Romanija and Bjelašnica locations; WBF-wild bilberry from the Fojnica location) in relation to sugars (gluc-glucose; fruc-fructose; sucr-sucrose; TS—-total sugars), organic acids (TA—total acids; mal-malic; cit—citric; shik—shikimic; fum-fumaric acid), glucose/fructose ratio (G/F) and sugar/acid ratio (s/a). (a) component 1 vs. component 2; (b) component 1 vs. component 3; (c) component 2 vs. component 3.

Figure 1a shows that the rosehip fruit is positioned in the negative part of component 2 . That means that the rosehip fruit from the Bugojno, Drvar and Foča locations is dominantly determined by sucrose, S/A ratio, fructose, total sugars and glucose. The rosehip from the Konjic location is in the positive part of component 3 (Figure $1 \mathrm{~b}$ ), and it is dominantly determined by G/F ratio as well as glucose content. Considering the results presented in Figure 1c, it is evident that rosehip from Foča stands out by its S/A ratio. Regardless of origin, the cornelian cherry is in the negative part of the first component, and shikimic, malic and fumaric acid, glucose, fructose, total acids and total sugars, as well as G/F ratio, dominantly determine the first component. Cornelian cherry samples originating 
from Drvar and Konjic are located in the positive part of the second component, so in relation to the other two locations, cornelian cherry stands out by its content of citric, malic and fumaric acid, as well as its total acids.

Wild strawberry and bilberry samples are in the positive part of the first component, and they are dominantly determined by citric acid content, and somewhat less than that by sucrose content and the sugar and acid ratio. However, Figure $1 \mathrm{~b}, \mathrm{c}$ indicate that bilberry in relation to wild strawberry stands out by its glucose content and G/F ratio. On the other hand, in relation to bilberry, strawberries stand out by sucrose content, malic acid and total acids.

\subsection{Correlation Coefficients}

Table 5 presents correlation coefficients between environmental factors (precipitation, average monthly air temperatures and altitude) on the analyzed chemical parameters of cornelian cherry and rosehip.

Table 5. Correlation coefficients between rainfall, temperature, altitude and the content of sugars and organic acids.

\begin{tabular}{|c|c|c|c|c|c|c|c|c|c|c|c|c|}
\hline & & Sucr & Gluc & Fruc & TS & $\mathrm{G} / \mathrm{F}$ & Mal & Shik & Cit & Fum & TA & S/A \\
\hline \multirow{2}{*}{$\mathrm{Tm}$} & DR & $0.80 * *$ & $0.68 * *$ & $0.90 * *$ & $0.83 * *$ & $-0.75 * *$ & $-0.83 * *$ & $-0.74 * *$ & $-0.92 * *$ & -0.11 & $-0.85 * *$ & $0.85 * *$ \\
\hline & $\mathrm{CC}$ & 0.62 & 0.60 & 0.42 & 0.56 & 0.42 & -0.64 & -0.14 & $-0.73\left(^{*}\right)$ & -0.66 & -0.62 & 0.65 \\
\hline \multirow{2}{*}{ Alt } & DR & $-0.65 * *$ & $-0.74 * *$ & $-0.78^{* *}$ & $-0.78 * *$ & 0.38 & 0.47 * & 0.20 & $0.55 * *$ & -0.05 & $0.47 *$ & $-0.56^{* *}$ \\
\hline & $\mathrm{CC}$ & -0.66 & $-0.75 *$ & $-0.78 *$ & $-0.78 *$ & 0.40 & 0.47 & 0.20 & 0.57 & -0.05 & 0.47 & -0.56 \\
\hline \multirow{2}{*}{ Ppt } & DR & 0.13 & 0.30 & -0.03 & 0.11 & $-0.53 * *$ & 0.29 & 0.17 & 0.38 & 0.07 & 0.31 & -0.20 \\
\hline & $\mathrm{CC}$ & 0.14 & 0.30 & -0.03 & 0.11 & 0.56 & 0.29 & 0.17 & 0.39 & 0.07 & 0.31 & -0.20 \\
\hline
\end{tabular}

DR—dog rose; CC—cornelian cherry; Gluc-glucose; Fruc—-fructose; Sucr-sucrose; TS—total sugar; TA—total acid; Mal—malic; Cit—citric; Shik—shikimic; Fum—fumaric acid; G/F—glucose/fructose ratio; S/A—sugar/acid ratio; $\mathrm{Tm}$ - mean monthly air temperature $\left({ }^{\circ} \mathrm{C}\right) ; \mathrm{Ppt}$-quantity of rainfall $(\mathrm{mm})$; Alt—altitude $(\mathrm{m})$; ${ }^{*}$ - significance at $p \leq 0.05 ;{ }^{* *}$-significance at $p \leq 0.01$.

By analyzing correlation coefficients of rosehip in relation to temperature, significance was found with respect to content of individual sugars, individual acids (except for fumaric acid), S/A and G/F ratios. Individual sugar content and S/A ratio showed positive correlation with temperature. Conversely, negative correlations between temperature and individual acids and G/F ratio were found. The lowest correlation coefficient -0.74 was in relation to shikimic acid, while the highest, +0.90 , was in relation to fructose.

According to altitude, significance was found in relation to all parameters of sugar, malic, citric and total acids, as well as sugar and acid ratio. Malic, citric and total acids showed a positive correlation while each sugar and S/A were negatively correlated with altitude. The lowest significant correlation coefficient, +0.47 , was in relation to malic and total acids, while the highest, -0.78 , was in relation to fructose and total sugars. Correlation coefficient significance of the analyzed characteristics in relation to annual precipitation was established for only the G/F ratio, and it was -0.53 . Analyzing the correlation coefficients of cornelian cherry in relation to temperature, significance was established only in relation to citric acid content, and it was -0.73 .

Concerning cornelian cherry, the altitude correlated significantly with glucose, fructose and total sugars, and these correlations were negative, as well as in the case of rosehip. These findings agree with those reported by Ercisli [16], who found that higher total soluble solid (TSS) and total dry weight (TDW) content are desirable fruit characteristics of rosehips, and both characteristics are strongly affected by altitude.

On the other hand, for cornelian cherry, no correlation coefficient significance was established for the characteristics investigated in relation to annual precipitation. Bijelić et al. [56] established the interdependence of cornelian cherry's physicochemical parameters and environmental conditions. Significant influence of environmental factors on the synthesis of secondary metabolites in the species Cornus mas was established, while synthesis of these components was less influenced by external factors in the case of Cornus sanguinea [65]. Considering that wild strawberry and bilberry did not show 
significant correlation of environmental factors with analyzed parameters of qualities, their results for this study are not presented in Table 5.

\section{Conclusions}

Analyzed individual sugars and organic acids were detected in all wild fruit species. An influence of location and growing year was established within the same fruit species (cornelian cherry, rosehip and wild strawberry), and growing year for bilberry, on individual and total sugars and organic acids, which are the most important factors in the characterization of wild fruit from a nutritive perspective, as well as for processing the fruit into valuable products and proving their authenticity.

Based on the S/A ratio results, rosehip fruits are recommended for the production of "pekmez" and drying, while genotypes of cornelian cherry, wild strawberry and bilberry, with lower S/A, are suitable for the production of juices and gelatin products. A significant influence of environmental factors on the synthesis of analyzed primary metabolites in cornelian cherry and rosehip species was established, while this influence was not established in the case of wild strawberry and bilberry species.

The results obtained on wild fruit species expand knowledge about the nutritionally valuable components that contribute to health protection and that the fruit may be widely used in the food industry as functional food as well as in medicine. According to these findings, it is necessary for future research to focus on the detection and quantification of polyphenol components in this valuable plant material, which can prevent the occurrence of disease and ensure a better quality of life.

Author Contributions: Conceptualization, A.A.; methodology, A.A., A.V.O., M.H. and N.S.; software, M.H., A.V.O. and A.B.; validation, M.H., A.B. and A.V.O.; formal analysis, A.A., S.O.Ž., A.B., M.H. and A.V.O.; investigation, A.A., N.S., S.O.Ž., P.D. and S.M.; resources, A.A., S.O.Ž., S.M. and P.D.; writing-original draft preparation, A.A., A.B., P.D. and N.S.; writing—review and editing, A.A., M.H., S.O.Ž.; funding acquisition, A.A., S.O.Ž., M.H. and S.M. All authors have read and agreed to the published version of the manuscript.

Funding: This research was funded under the Programme in Higher Education, Research and Development in the Western Balkans (HERD/Agriculture), grant number RN 332160 (Norway) and programme Horticulture No. P4-0013-0481 funded by the Slovenian Research Agency.

Acknowledgments: The authors thank Federal Hydrometeorological Service Sarajevo and Republic Hydrometeorological Service Banja Luka for sharing meteorological data

Conflicts of Interest: The authors declare no conflict of interest.

\section{References}

1. Hegazy, A.K.; Al-Rowaily, S.L.; Faisal, M.; Alatar, A.A.; El-Bana, M.I.; Assaeed, A.M. Nutritive value and antioxidant activity of some edible wild fruits in the Middle East. J. Med. Plant Res. 2013, 7, 938-946. [CrossRef]

2. Chakravarty, S.; Bhutia, K.D.; Suresh, C.P.; Shukla, G.; Pala, N.A. A review on diversity, conservation and nutrition of wild edible fruits. J. Nat. Appl. Sci. 2016, 8, 2346-2353. [CrossRef]

3. Redzic, S. Wild edible plants and their traditional use in the human nutrition in Bosnia-Herzegovina. Ecol. Food Nutr. 2006, 45, 189-232. [CrossRef]

4. Najda, A.; Dyduch, M. Chemical diversity within wild strawberry (Fragaria vesca L.) species. Herba Pol. 2009, 55, 140-160.

5. Ercisli, S.; Sagbas, H.I. Wild edible fruits: A rich source of biodiversity. Anadolu (J. AARI) 2017, $27,116-122$.

6. Rimpapa, Z.; Toromanović, J.; Tahirović, I.; Šapčanin, A.; Sofić, E. Total content of phenols and anthocyanins in edible fruits from Bosnia. Bosnia J. Basic Med. Sci. 2007, 7, 119-122. [CrossRef]

7. Giovanelli, G.; Buratti, S. Comparison of polyphenolic composition and antioxidant activity of wild Italian blueberries and some cultivated varieties. Food Chem. 2009, 112, 903-908. [CrossRef]

8. Bunea, A.; Rugină, O.D.; Pintea, M.A.; Sconţa, Z.; Bunea, I.C.; Socaciu, C. Comparative polyphenolic content and antioxidant activities of some wild and cultivated blueberries from Romania. Not. Bot. Horti Agrobo. 2011, 39, 70-76. [CrossRef]

9. Milivojević, J.; Maksimović, V.; Nikolić, M.; Bogdanović, J.; Maletić, R.; Milatović, D. Chemical and antioxidant properties of cultivated and wild Fragaria and Rubus berries. J. Food Qual. 2011, 34, 1-9. [CrossRef] 
10. Stajčić, M.S.; Tepić, N.A.; Djilas, M.S.; Šumić, M.Š.; Čanadanović-Brunet, M.J.; Ćetković, S.G.; Vulić, J.J.; Tumbas, T.V. Chemical composition and antioxidant activity of berry fruits. Acta Period. Technol. 2012, 43, 93-105. [CrossRef]

11. Badjakov, I.; Nikolova, M.; Gevrenova, R.; Kondakova, V.; Todorovska, E.; Atanassov, A. Bioactive compounds in small fruits and their influence on human health. Biotechnol. Biotechnol. Equip. 2008, 22, 581-587. [CrossRef]

12. Liu, R.H. Health-promoting components of fruits and vegetables in the diet. Adv. Nutr. 2013, 4, 384S-392S. [CrossRef] [PubMed]

13. Taneva, I.; Petkova, N.; Dimov, I.; Ivanov, I.; Denev, P. Characterization of rose hip (Rosa canina L.) fruits extracts and evaluation of their in vitro antioxidant activity. J. Pharmacogn. Phytochem. 2016, 5, 35-38.

14. Virgolin, L.B.; Seixas, F.R.F.; Janzantti, N.S. Composition, content of bioactive compounds, and antioxidant activity of fruit pulps from the Brazilian Amazon biome. Pesqui. Agropecu. Bras. 2017, 52, 933-941. [CrossRef]

15. Patel, S. Rose hip as an underutilized functional food: Evidence-based review. Trends Food Sci. Technol. 2017, 63, 29-38. [CrossRef]

16. Ercisli, S. Chemical composition of fruits in some rose (Rosa spp.) species. Food Chem. 2007, 104, 1379-1384. [CrossRef]

17. Wang, S.Y.; Chen, C.-T.; Wang, C.Y. The influence of light and maturity on fruit quality and flavonoid content of red raspberries. Food Chem. 2009, 112, 676-684. [CrossRef]

18. Pedisic, S.; Dragovic-Uzelac, V.; Levaj, B.; Skevin, D. Effect of maturity and geographical region on anthocyanin content of sour cherries (Prunus cerasus var. 'Marasca'). Food Technol. Biotech. 2010, 48, 86-93.

19. Begić-Akagić, A.; Drkenda, P.; Vranac, A.; Orazem, P.; Hudina, M. Influence of growing region and storage time on phenolic profile of cornelian cherry jam and fruit. Eur. J. Hortic. Sci. 2013, 78, 30-39.

20. Kevers, C.; Pincemail, J.; Defraigne, J.O.; Dommes, J. Antioxidant capacity of small dark fruits: Influence of cultivars and harvest time. J. Berry Res. 2014, 4, 97-105. [CrossRef]

21. Rodica, S.; Bonea, D.; Iancu, P.; Niculescu, M. Biochemical and technological properties of Rosa canina L. fruits from spontaneous flora of Oltenia, Romania. Bull. Univ. Agric. 2015, 72, 182-186.

22. Dugalic, K.; Sudar, R.; Viljevac, M.; Josipović, M.; Cupic, T. Sorbitol and sugar composition in plum fruits influenced by climatic conditions. J. Agric. Sci. Tech. 2014, 16, 1145-1155.

23. Güneş, M.; Dölek, Ü.; Elmastaş, M. Pomological changes in some rosehip species during ripening. JAFAG 2016, 33, 214-222. [CrossRef]

24. Cretescu, I.; Ropciuc, S.; Leahu, A. Evaluation of rosehip fruit productivity and total acidity in response to climatic factors. Rom. Biotech. Lett. 2013, 18, 8403-8412.

25. Correia, S.; Gonçalves, B.; Aires, A.; Silva, A.; Ferreira, L.; Carvalho, R.; Fernandes, H.; Freitas, C.; Carnide, V.; Silva, A.P. Effect of harvest year and altitude on nutritional and biometric characteristics of blueberry cultivars. J. Chem. 2016, 12. [CrossRef]

26. Zoratti, L.; Jaakola, L.; Haggman, H.; Giongo, L. Anthocyanin profile in berries of wild and cultivated Vaccinium spp. along altitudinal gradients in Alps. J. Agric. Food Chem. 2015, 63, 8641-8650. [CrossRef]

27. Mikulic Petkovsek, M.; Schmitzer, V.; Slatnar, A.; Stampar, F.; Veberic, R. A comparison of fruit quality parameters of wild bilberry (Vaccinium myrtillus L.) growing at different location. J. Sci. Food Agric. 2015, 95, 776-785. [CrossRef]

28. Guerrero-Chavez, G.; Scampicchio, M.; Andreotti, C. Inflence of the site altitude on strawberry phenolic composition and quality. Sci. Hortic. (Amsterdam) 2015, 192, 21-28. [CrossRef]

29. Kafkas, E.; Kosar, M.; Türemis, N.; Baser, K.H.C. Analysis of sugars, organic acids and vitamin C contents of blackberry genotypes from Turkey. Food Chem. 2006, 97, 732-736. [CrossRef]

30. Tosun, M.; Ercisli, S.; Karlidag, H.; Sengul, M. Characterization of red raspberry (Rubus idaeus L.) genotypes for their physicochemical properties. J. Food Sci. 2009, 74, 575-579. [CrossRef]

31. Sha, S.; Li, J.; Wu, J.; Zhang, S. Characteristics of organic acids in the fruit of different pear species. Afr. J. Agric. Res. 2011, 6, 2403-2410. [CrossRef]

32. Akagić, A.; Vranac, A.; Gaši, F.; Drkenda, P.; Spaho, N.; Oručević Žuljević, S.; Kurtović, M.; Musić, O.; Murtić, S.; Hudina, M. Sugars, acids and polyphenols profile of commercial and traditional apple cultivars for processing. Acta Agric. Slov. 2019, 113/2, 239-251. [CrossRef]

33. Vukoja, J.; Pichler, A.; Kopjar, M. Stability of Anthocyanins, Phenolics and Color of tart Cherry jams. Foods 2019, 8, 255. [CrossRef] [PubMed] 
34. Lozano, J.E. Fruit Manufacturing-Scientific Basis, Engineering Properties, and Deteriorative Reactions of Technological Importance; Springer: New York, NY, USA, 2006; pp. 136-141.

35. Evans, R.H.; Van Soestbergen, A.W.; Ristow, K.A. Evaluation of apple juice authenticity of organic acid analysis. J. Assoc. Off. Anal. Chem. 1983, 66, 1517-1520. [CrossRef]

36. Coppola, E.D.; Starr, M.S. Liquid chromatographic determination of major organic acids in apple juice and cranberry juice cocktail: Collaborative study. J. Assoc. Off. Anal. Chem. 1986, 69, 594-597. [CrossRef]

37. AIJN Europen Fruit Juice Association, The AIJN Code of Practice. 2006. Available online: https://aijn.eu/en/ the-aijn-code-of-practice (accessed on 10 June 2008).

38. Pirie, A.; Mullins, M.G. Interrelationships of sugars, anthocyanins, total phenols and dry weight in the skin of grape berries during ripening. Am. J. Enol. Viticult. 1977, 28, 204-209.

39. Abidi, W.; Jimènez, S.; Moreno, M.Á.; Gogorcena, Y. Evaluation of antioxidant compounds and total sugar content in a nectarine [Prunus persica (L.) Batsch] progeny. Int. J. Mol. Sci. 2011, 12, 6919-6935.

40. Milivojević, J.; Rakonjac, V.; Fotirić Akšić, M.; Bogdanović Pristov, J.; Maksimović, V. Classification and fingerprinting of different berries based on biochemical profiling and antioxidant capacity. Pesqui. Agropecu. Bras. 2013, 48, 1285-1294. [CrossRef]

41. Redzic, S.; Dalmatin, M.; Hamidovic, M.; Kadic, J.; Radevic, M.; Sevo, L. Biodiversity, geo-diversity and protection of natural and cultural heritages. Natl. Environ. Action Plan Bosnia Herzeg. 2003, Sarajevo, 67-76.

42. Marjanovic-Balaban, Z.; Grujic, S.; Jasic, M.; Vujadinovic, D. Testing of chemical composition of wild berries. Third Int. Sci. Symp. 2012, 154-161. [CrossRef]

43. Tuzlak, A.; Begić-Akagić, A. Stability of Bioactive Components in Cornelian Cherry Jam During Production and Storage. Work. Fac. Agric. Food Sci. Univ. Sarajevo 2012, 62, 187-201.

44. Islamovic, A.; Mlaco, M.; Berbic, N.; Begic-Akagic, A.; Orucevic, S.; Bulbulusic, A.; Ekeberg, D.; Drkenda, P. Seasonal variation of the physical and chemical parameters of wild genotypes cornelian cherry (Cornus mas L.). J. Int. Sci. Publ. Agric. Food 2014, 2, 466-471.

45. Akagić, A.; Mlačo, M.; Islamović, A.; Oručević Žuljević, S.; Vranac, A.; Kallenborn, R. Influence of Fruit Properties of Rose Hips on Pekmez Quality. In Proceedings of the 3rd International Symposium on "Traditional Foods from Adriatic to Caucasus", Sarajevo, Bosna i Hercegovina, 1-4 October 2015; Volume 370.

46. Tahirović, A.; Bašić, A. Determination of phenolic content and antioxidant activity of Rosa canina L. fruits in different extraction systems. Work. Fac. For. Univ. Sarajevo 2017, 1, 47-59.

47. Drkenda, P.; Spahic, A.; Begic-Akagic, A.; Gasi, F.; Vranac, A.; Blanke, M. Pomological characteristics of some autochthonous genotypes of cornelian cherry (Cornus mas L.) in Bosnia and Herzegovina. Erwerbs-Obstbau 2014, 56, 59-66. [CrossRef]

48. Hudina, M.; Stampar, F. Influence of frost damage on the sugars and organic acids contents in apple and pear flowers. Eur. J. Hortic. Sci. 2006, 71, 161-164.

49. Begić-Akagić, A.; Spaho, N.; Gaši, F.; Drkenda, P.; Vranac, A.; Meland, M.; Salkić, B. Sugar and organic acid profiles of traditional and international apple cultivars for processing. J. Hyg. Eng. Des. 2014, 190-196.

50. Hecke, K.; Herbinger, K.; Veberic, R.; Trobec, M.; Toplak, H.; Stampar, F.; Keppel, H.; Grill, D. Sugar, acid, and phenol contents in apple cultivars from organic and integrated fruit cultivation. Eur. J. Clin. Nutr. 2006, 60, 1136-1140. [CrossRef]

51. Montesano, D.; Cossignani, L.; Giua, I.; Urbani, E.; Simonetti, M.S.; Blasi, F. A Simple HPLC-ELSD method for sugar analysis in goji berry. J. Chem. 2016. [CrossRef]

52. Rosu, C.M.; Manzu, C.; Olteanu, Z.; Oprica, L.; Oprea, A.; Todirascu-Ciornea, E.; Zamfirache, M.M. Several fruit characteristics of Rosa sp. genotypes from the Northeastern region of Romania. Not. Bot. Horti Agrobot. 2011, 39, 203-208. [CrossRef]

53. Saeidi, K.A.; Beygi, O.R. Determination of phenolics, soluble carbohydrates, carotenoid contents and minerals of dog rose (Rosa canina L.) fruits grown in south-west of Iran. Iran. J. Med. Arom Plants 2009, 25, $203-215$.

54. Barros, L.; Carvalho, A.M.; Ferreira, I. Exotic fruits as a source of important phytochemicals: Improving the traditional use of Rosa canina fruits in Portugal. Food Res. Int. 2011, 44, 2233-2236. [CrossRef]

55. Tural, S.; Koca, I. Physico-chemical and antioxidant properties of cornelian cherry fruits (Cornus mas L.) grown in Turkey. Sci. Hortic. (Amsterdam) 2008, 116, 362-366. [CrossRef]

56. Bijelić, S.; Gološin, B.; Ninić-Todorović, J.; Cerović, S.; Popović, B. Physicochemical fruit characteristics of cornelian cherry (Cornus mas L.) genotypes from Serbia. Genet. Resour. Crop Evol. 2011, 58, 689-695. [CrossRef] 
57. Leeuwen, C.V.; Friant, P.; Choné, X.; Tregoat, O.; Koundouras, S.; Dubourdieu, D. Influence of climate, soil, and cultivar on Terroir. Am. J. Enol. Viticult. 2004, 55, 207-217.

58. Viljakainen, S.; Visti, A.; Laakso, S. Concetrations of organic acids and solubile sugars in juices from Nordic berries. Acta Agric. Scand. Sect. B-Plant Soil Sci. 2002, 52, 101-109.

59. Demir, F.; Özcan, M. Chemical and technological properties of rose (Rosa canina L.) fruits grown wild in Turkey. J. Food Eng. 2001, 47, 333-336. [CrossRef]

60. Mikulic Petkovsek, M.; Schmitzer, V.; Slatnar, A.; Stampar, F.; Veberic, R. Composition of sugars, organic acids and total phenolics in 25 wild or cultivated berry Species. J. Food Sci. 2012, 1-7. [CrossRef]

61. Ercisli, S.; Orhan, S. Chemical composition of white (Morus alba), red (Morus rubra) and black (Morus nigra) mulberry fruits. Food Chem. 2007, 103, 1380-1384. [CrossRef]

62. Panico, A.M.; Garufi, F.; Nitto, S.; Mauro, R.; Longhitano, R.C.; Magri, G.; Catalfo, A.; Serrentino, M.E.; Guidi, G. Antioxidant activity and phenolic content of strawberry genotypes from Fragaria $\times$ ananassa. Pharm. Biol. 2009, 47, 203-208. [CrossRef]

63. Mikulic Petkovsek, M.; Stampar, F.; Veberic, R. Parameters of inner quality of the apple scab resistant and susceptible apple cultivars (Malus domestica Borkh.). Sci. Hortic. (Amsterdam) 2007, 114, 37-44. [CrossRef]

64. Begic-Akagic, A.; Alekic, A.; Orucevic, S.; Kallenborn, R.; Berbic, N.; Islamovic, A.; Drkenda, P.; Vranac, A. Influence of production method on phenol content of rose hip "pekmez". In Proceedings of the 24th International Scinetific-Expert Conference of Agriculture and Food Industry, Sarajevo, Bosnia and Herzegovina, 25-28 September 2013; Blesić, M., Ed.; Faculty of Agriculture and Food Sciences, University of Sarajevo: Sarajevo, Bosnia and Herzegovina, 2013; pp. 229-234.

65. Popović, Z.; Matić, R.; Bajić-Ljubičić, J.; Tešević, V.; Bojović, S. Geographic variability of selected phenolic compounds in fresh berries of two Cornus species. Trees 2018, 31, 2003-2014. [CrossRef]

(C) 2020 by the authors. Licensee MDPI, Basel, Switzerland. This article is an open access article distributed under the terms and conditions of the Creative Commons Attribution (CC BY) license (http://creativecommons.org/licenses/by/4.0/). 